\title{
Response of Enteromorpha sp. (Chlorophyceae) to a nitrate pulse: nitrate uptake, inorganic nitrogen storage and nitrate reductase activity
}

\author{
Julien Lartigue ${ }^{1,2,4, *}$, Timothy D. Sherman ${ }^{3}$ \\ ${ }^{1}$ Dauphin Island Sea Lab, 101 Bienville Boulevard, Dauphin Island, Alabama 36528, USA \\ ${ }^{2}$ Department of Marine Sciences, University of South Alabama, LSCB-25, Mobile, Alabama 36688, USA \\ ${ }^{3}$ Department of Biology, University of South Alabama, LSCB-124, Mobile, Alabama 36688, USA
}

${ }^{4}$ Present address: Marine Science Institute, University of Texas at Austin, 750 Channel View Drive, Port Aransas, Texas 78373, USA

\begin{abstract}
The uptake, storage and reduction of nitrate $\left(\mathrm{NO}_{3}^{-}\right)$by Enteromorpha sp. during a $\mathrm{NO}_{3}{ }^{-}$ pulse was studied in the laboratory using algae collected from the Mobile Bay estuary, Alabama, USA. Peak uptake occurred when Enteromorpha sp. was initially exposed to $\mathrm{NO}_{3}{ }^{-}$. As the internal $\mathrm{NO}_{3}{ }^{-}$pool filled, $\mathrm{NO}_{3}{ }^{-}$uptake declined. After $6 \mathrm{~h}$ of exposure to a $30 \mu \mathrm{M} \mathrm{NO}_{3}{ }^{-}$pulse, the tissue $\mathrm{NO}_{3}{ }^{-}$ pool was filled and $\mathrm{NO}_{3}^{-}$uptake decreased to $1.64 \pm 2.63 \mu \mathrm{mol} \mathrm{NO}{ }^{-} \mathrm{g}^{-1}$ fresh $\mathrm{wt} \mathrm{h}^{-1}$. While tissue $\mathrm{NO}_{3}{ }^{-}$increased when $\mathrm{NO}_{3}^{-}$became available, the size of the internal nitrite $\left(\mathrm{NO}_{2}^{-}\right)$, ammonium $\left(\mathrm{NH}_{4}{ }^{+}\right.$), and free amino acid (FAA) pools remained roughly constant, suggesting that reduction of $\mathrm{NO}_{3}{ }^{-}$to nitrite $\left(\mathrm{NO}_{2}{ }^{-}\right)$by nitrate reductase (NR) was the rate-limiting step in $\mathrm{NO}_{3}{ }^{-}$assimilation. Meanwhile, there was a lag time (2 to $3 \mathrm{~h})$ between exposure to $\mathrm{NO}_{3}{ }^{-}$and peak NR activity $(0.80 \pm$ $0.23 \mu \mathrm{mol} \mathrm{NO}{ }_{2}^{-} \mathrm{g}^{-1}$ fresh $\mathrm{wt} \mathrm{h}^{-1}$ ). These characteristics, combined with a peak NR activity that was 11 -fold less than the peak $\mathrm{NO}_{3}{ }^{-}$uptake rate, suggest that during a $\mathrm{NO}_{3}{ }^{-}$pulse the internal $\mathrm{NO}_{3}{ }^{-}$pool quickly fills and uptake becomes limited by the rate at which the internal $\mathrm{NO}_{3}{ }^{-}$pool is reduced by NR. Predicted levels of tissue $\mathrm{NO}_{3}{ }^{-}$calculated from initial tissue $\mathrm{NO}_{3}{ }^{-}, \mathrm{NO}_{3}{ }^{-}$uptake and $\mathrm{NR}$ activity agreed with the measured tissue $\mathrm{NO}_{3}{ }^{-}$.
\end{abstract}

KEY WORDS: Nitrate pulse $\cdot$ Nitrate uptake $\cdot$ Nitrate reductase $\cdot$ Enteromorpha sp. $\cdot$ Mobile Bay estuary $\cdot$ Ammonium $\cdot$ Free amino acids

\section{INTRODUCTION}

Macroalgae make significant contributions to primary production in many coastal and estuarine systems (Smith 1981, Pregnall \& Rudy 1985, Sfriso et al. 1987, Peckol \& Rivers 1996, Hernandez et al. 1997, Valiela et al. 1997, Martins \& Pardal 2001). It is not uncommon for this macroalgal production to be limited by the availability of nitrogen during at least a portion of the year (Fujita et al. 1989, Lapointe et al. 1992, Wheeler \& Björnsäter 1992, Fong et al. 1993, ThyboChristesen et al. 1993, Pedersen \& Borum 1996). When nitrogen is limiting, macroalgal production can be released from limitation by the delivery of inorganic nitrogen in the form of nitrate $\left(\mathrm{NO}_{3}{ }^{-}\right)$or ammonium $\left(\mathrm{NH}_{4}{ }^{+}\right)$.

The delivery of $\mathrm{NO}_{3}{ }^{-}$is frequently episodic, occurring in pulses whose duration and magnitude are unpredictable (Chapman \& Craige 1977, Nixon \& Pilson 1983, Fujita et al. 1989, Hernandez et al. 1997). In estuaries, variability in the availability of $\mathrm{NO}_{3}{ }^{-}$often results from changes in river flow (Wafar et al. 1989, Selmer \& Rydberg 1993). Depending on the residence time of estuarine water during these pulse events, $\mathrm{NO}_{3}{ }^{-}$may only be available for a few hours or days. Consequently, the high $\mathrm{NO}_{3}{ }^{-}$loads in estuarine inputs will only be translated into macroalgal production if macroalgae are capable of removing $\mathrm{NO}_{3}{ }^{-}$from the 
water column at the time scale of estuarine water renewal.

While macroalgae have the capacity to store inorganic nitrogen (Rosenberg \& Ramus 1982, Duke et al. 1987, Fong et al. 1994), this capacity is finite. Once the internal $\mathrm{NO}_{3}{ }^{-}$pool is filled, further utilization of a $\mathrm{NO}_{3}{ }^{-}$ pulse is restricted by the rate of $\mathrm{NO}_{3}{ }^{-}$assimilation. Particularly for ephemeral macroalgae (e.g. the genera Enteromorpha, Ulva, Cladophora), whose growth rates and nitrogen demands are high (Harlin 1978, Björnsäter \& Wheeler 1990, Wheeler \& Björnsäter 1992, Pedersen \& Borum 1997), rapid $\mathrm{NO}_{3}^{-}$assimilation will mean a larger portion of a $\mathrm{NO}_{3}{ }^{-}$pulse can be utilized.

Nitrate assimilation begins with the reduction of $\mathrm{NO}_{3}{ }^{-}$to nitrite $\left(\mathrm{NO}_{2}{ }^{-}\right)$via the enzyme nitrate reductase (NR) (Solomonson \& Barber 1990). This initial step is thought to frequently limit the overall rate of $\mathrm{NO}_{3}{ }^{-}$ assimilation (Solomonson \& Barber 1990, Berges \& Harrison 1995, Berges 1997). Thus, once the internal $\mathrm{NO}_{3}{ }^{-}$pool is filled, further utilization of a $\mathrm{NO}_{3}{ }^{-}$pulse may well be limited by the activity of NR. The synthesis and activation of NR is regulated primarily by the presence or absence of $\mathrm{NO}_{3}{ }^{-}$(Solomonson \& Barber 1990, Crawford 1995). However, ammonium, light, circadian rhythms, iron, and carbon and nitrogen metabolites are factors that can also control NR activity (Solomonson \& Barber 1990, Crawford 1995, Kudo et al. 2000, Milligan \& Harrison 2000). Because NR is regulated by synthesis and degradation cycles as well as post-translational mechanisms such as phosphorylation, NR activity can change rapidly in response to changes in the availability of $\mathrm{NO}_{3}{ }^{-}$and the other controlling factors (Solomonson \& Barber 1990, Huber et al. 1992).

While several studies have focused on NR activity in macroalgae (Davison et al. 1984, Corzo \& Neill 1992, Lopes et al. 1997), no study has yet investigated how $\mathrm{NO}_{3}{ }^{-}$uptake and $\mathrm{NR}$ activity respond to the sudden availability of $\mathrm{NO}_{3}{ }^{-}$or how this response changes over time as the internal $\mathrm{NO}_{3}{ }^{-}$pool fills. Thomas \& Harrison (1985) did measure $\mathrm{NO}_{3}{ }^{-}$uptake, tissue $\mathrm{NO}_{3}{ }^{-}$and $\mathrm{NR}$ activity in Porphyra perforata under inorganic nitrogen enrichment and nitrogen limitation, but their measurements were taken $24 \mathrm{~h}$ apart and spread over several days. Hwang et al. (1987) also reported values for $\mathrm{NO}_{3}^{-}$uptake, tissue $\mathrm{NO}_{3}^{-}$, and $\mathrm{NR}$ activity for Gracilaria tikvahiae after $24 \mathrm{~h}$ nitrogen limitation and $13 \mathrm{~h}$ nitrate enrichment. However, Hwang et al. (1987) did not measure NR activity directly, but estimated it as the difference between the rate the tissue $\mathrm{NO}_{3}{ }^{-}$pool was filled and emptied.

In this study, we have focused on the response of Enteromorpha sp. from the Mobile Bay estuary, Alabama, to a $\mathrm{NO}_{3}{ }^{-}$pulse. Blooms of Enteromorpha sp. and other ephemeral macroalgae are common in nutri- ent-enriched estuaries worldwide (Fletcher 1996 [review], Rafaelli et al. 1998 [review]). While large blooms of Enteromorpha sp. are rare in the Mobile Bay estuary, stands of Enteromorpha sp. appear annually from October to May. The Mobile Bay estuary is a shallow, dynamic body of water (mean depth $3.0 \mathrm{~m}$ ), where wind and tidal forcing, along with river discharge, combine to determine water movement (Stumpf et al. 1993, Pennock et al. 1994a). Nitrate concentrations range from near 0 to roughly $30 \mu \mathrm{M}$ within the estuary, with pulses of $\mathrm{NO}_{3}{ }^{-}$coinciding with wind and rain events (Pennock et al. 1994b, Lartigue 2003). During these pulse events, $\mathrm{NO}_{3}{ }^{-}$concentrations can remain above $20 \mu \mathrm{M}$ for periods of minutes to days, depending on the location, amount of runoff and tidal cycle. In general, $\mathrm{NO}_{3}{ }^{-}$concentrations in the Mobile Bay estuary are lower and $\mathrm{NO}_{3}{ }^{-}$pulses smaller than in more enriched estuaries (Sfriso et al. 1992, Flindt et al. 1997, Naldi \& Viaroli 2002).

The purpose of this study was to test the response of Enteromorpha sp. to a $\mathrm{NO}_{3}{ }^{-}$pulse similar in magnitude to those documented in the Mobile Bay estuary. Specifically, we tested the following 2 hypotheses: (1) Entermorpha sp. can take up $\mathrm{NO}_{3}{ }^{-}$during a pulse event; (2) NR activity and not the rate of $\mathrm{NO}_{3}{ }^{-}$uptake limits how much $\mathrm{NO}_{3}{ }^{-}$is taken up during a pulse event. In addition, we calculated a $\mathrm{NO}_{3}{ }^{-}$budget to determine if the measures of $\mathrm{NO}_{3}{ }^{-}$uptake, inorganic nitrogen storage and NR activity could predict the observed changes in the internal $\mathrm{NO}_{3}{ }^{-}$pool.

\section{MATERIALS AND METHODS}

Collection and pre-treatment. In March of 2001 and 2002, rocks (surface area 80 to $200 \mathrm{~cm}^{2}$ ) with attached Enteromorpha sp. (6 to $10 \mathrm{~g}$ fresh wt were collected from the east end of Dauphin Island, Alabama, USA $\left(30^{\circ} 15.015^{\prime} \mathrm{N}, 88^{\circ} 04.759^{\prime} \mathrm{W}\right)$, rinsed with seawater (SW), and transported ( $5 \mathrm{~min})$ to the Dauphin Island Sea Lab. In the laboratory, the rocks and attached algae were briefly submerged in freshwater to remove any remaining invertebrates and then placed in a pretreatment tank containing $20 \mathrm{l}$ of nitrogen-depleted filtered seawater (FSW). The seawater used in this study was pumped from the collection site to a settling tank, where $\mathrm{NO}_{3}{ }^{-}$and $\mathrm{NH}_{4}{ }^{+}$concentrations declined to $<1 \mu \mathrm{M}$, and then filtered through a $1.0 \mu \mathrm{m}$ polypropylene felt-bag filter (Aquatic Ecosystems).

Each pre-treatment began at 09:00 $\mathrm{h}$ and ensured that Enteromorpha sp. collected on different days had been exposed to similar nutrient and light conditions prior to the pulse experiments. During the $24 \mathrm{~h}$ pretreatment, the alga was held at $200 \mu \mathrm{mol} \mathrm{m}{ }^{-2} \mathrm{~s}^{-1}$ photosynthetically active radiation (PAR), 20 practical salin- 
ity units (psu), and $22^{\circ} \mathrm{C}$. Initial and final water samples confirmed that the pre-treatment water was depleted of nitrogen $\left(\mathrm{NO}_{3}{ }^{-}, \mathrm{NO}_{2}^{-}\right.$and $\mathrm{NH}_{4}{ }^{+}$concentrations $<1 \mu \mathrm{M})$. These water samples were filtered (GF/C) (VWR International), frozen at $-80^{\circ} \mathrm{C}$, and later analyzed for $\mathrm{NO}_{3}{ }^{-}, \mathrm{NO}_{2}{ }^{-}$and $\mathrm{NH}_{4}{ }^{+}$concentration using a Sans ${ }^{\text {plus }}$ Systems autoanalyzer (SKALAR) according to the protocol outlined in the manual (SKALAR 1996). Illumination was provided by 4 Sylvania Cool White 215W VHO fluorescent bulbs (Sylvania) along with 4 $100 \mathrm{~W}$ halogen bulbs (General Electric Lighting) during the pre-treatment and the subsequent pulse experiments. Irradiance was measured with a LI-192SA underwater quantum sensor attached to a LI-1000 data logger (LICOR).

Nitrate pulse experiments. Following the pre-treatment, each rock with attached Enteromorpha sp. was randomly assigned to a control tank containing no $\mathrm{NO}_{3}{ }^{-}$or an experimental tank enriched with sodium nitrate $\left(\mathrm{NaNO}_{3}^{-}\right)$. Each tank held $1501 \mathrm{FSW}$ and was mixed by aeration. Salinity, temperature and irradiance were identical to those in pre-treatment conditions. Control and experimental tanks were set up each day and the experiment was repeated on successive days using freshly collected algae until at least 5 control and 5 experimental tanks had been run.

We performed 2 sets of pulse experiments. In the longer pulse experiment (12 h), sampling occurred at 0, 3, 6 and $12 \mathrm{~h}$ and $\mathrm{NO}_{3}{ }^{-}$concentrations of 0 (control) and $30 \mu \mathrm{M}$ were tested. In the shorter pulse experiment (3 h), sampling occurred at 0, 20, 40, 60, 120 and $180 \mathrm{~min}$ and $\mathrm{NO}_{3}{ }^{-}$concentrations of 0 (control), 6 and $30 \mu \mathrm{M}$ were tested. $\mathrm{All} \mathrm{NO}_{3}{ }^{-}$pulse experiments began at 09:00 h.

The large volume of water in each tank compared to the small amount of algae (0.04 to $0.07 \mathrm{~g}^{-1}$ fresh wt $\mathrm{l}^{-1}$ ) ensured that the $\mathrm{NO}_{3}{ }^{-}$concentration in each tank did not change appreciably over time. In the $12 \mathrm{~h}$ pulse experiment, the control tanks contained $<1 \mu \mathrm{M} \mathrm{NO}_{3}{ }^{-}$ and the $30 \mu \mathrm{M} \mathrm{NO}_{3}{ }^{-}$tanks contained between 25 and $30 \mu \mathrm{M} \mathrm{NO}_{3}^{-}$. In the $3 \mathrm{~h}$ pulse experiment, the control tanks contained $<1 \mathrm{\mu M} \mathrm{NO}_{3}{ }^{-}$, the $6 \mu \mathrm{M} \mathrm{NO}_{3}{ }^{-}$tanks between 4 and $6 \mu \mathrm{M} \mathrm{NO}_{3}{ }^{-}$, and the $30 \mu \mathrm{M} \mathrm{NO}_{3}{ }^{-}$tanks between 25 and $30 \mathrm{\mu M} \mathrm{NO}_{3}{ }^{-}$. All treatments contained $<1 \mu \mathrm{M} \mathrm{NO}_{2}{ }^{-}$and $\mathrm{NH}_{4}{ }^{+}$.

Approximately $1.0 \mathrm{~g}$ fresh wt of Enteromorpha sp. and a water sample were removed from each tank at the time intervals listed above. The initial $(0 \mathrm{~h})$ algal tissue sample and initial water sample were collected immediately before placing Enteromorpha sp. in a tank. Collected tissue was rinsed with FSW and assayed for $\mathrm{NO}_{3}{ }^{-}$uptake, tissue $\mathrm{NO}_{3}{ }^{-}$, tissue $\mathrm{NO}_{2}{ }^{-}$, tissue $\mathrm{NH}_{4}{ }^{+}$, free amino acids (FAA), and NR activity. Nitrate uptake was measured over $10 \mathrm{~min}$ in $50 \mathrm{ml}$ plastic centrifuge tubes containing $40 \mathrm{ml}$ of water taken from the same tank as a tissue sample. $\mathrm{NO}_{3}{ }^{-}$ uptake rate $\left(\mu \mathrm{mol} \mathrm{NO}_{3}{ }^{-} \mathrm{g}^{-1}\right.$ fresh $\mathrm{wt} \mathrm{h}^{-1}$ ) was calculated from the difference in $\mathrm{NO}_{3}{ }^{-}$concentration between a tube that had contained algae and a tube that had only contained water from the tank. As a result, the uptake rates reported represent average uptake over the 10 min immediately following the time of tissue collection. Tissue $\mathrm{NO}_{3}{ }^{-}, \mathrm{NO}_{2}{ }^{-}, \mathrm{NH}_{4}{ }^{+}$and FAA were extracted from $0.4 \mathrm{~g}$ fresh wt of Enteromorpha sp. homogenized with an OMNI 2000 homogenizer (OMNI International) in $45 \mathrm{ml}$ of deionized water. The homogenate was boiled for $10 \mathrm{~min}$, extracted for $24 \mathrm{~h}$ at $4^{\circ} \mathrm{C}$, and filtered $(\mathrm{GF} / \mathrm{C})$, before storage at $-80^{\circ} \mathrm{C}$. The filtrate was then later analyzed for $\mathrm{NO}_{3}{ }^{-}, \mathrm{NO}_{2}{ }^{-}$and $\mathrm{NH}_{4}{ }^{+}$concentration on the San ${ }^{\text {plus }}$ System autoanalyzer and for FAA concentration on a Perkin Elmer Luminescence Spectrometer (LS50B) according to the protocol outlined in Parsons et al. (1984), with glycine as the standard (Sigma Ultra $\geq 99 \%$, Sigma). To express the amount of FAA in $\mu \mathrm{mol} \mathrm{N}, 1 \mu \mathrm{mol}$ of glycine was considered equal to $1 \mu \mathrm{mol}$ of FAA and $1 \mu \mathrm{mol}$ of glycine-N was considered equal to $1 \mu \mathrm{mol}$ of FAA-N. NR activity was assayed using the in situ assay described in Lartigue \& Sherman (2002).

Algal fresh wt was determined after tissue samples had been pressed firmly between paper towels. Dry weight, determined after $24 \mathrm{~h}$ at $80^{\circ} \mathrm{C}$, averaged $12.0 \%$ of FW (95\% CI = 2.7\%, n = 113). Total nitrogen content for thalli dried at $80^{\circ} \mathrm{C}$ for at least $24 \mathrm{~h}$ and ground into a fine powder using a mortar and pestle was determined using a Carlo Erba CNS analyzer (NA 1500 Series 2).

Nitrate-balance calculations. Since the size of the tissue $\mathrm{NO}_{3}^{-}$pool is determined by the rate at which $\mathrm{NO}_{3}{ }^{-}$is taken up by algal cells and the rate of $\mathrm{NO}_{3}{ }^{-}$ reduction by NR within algal cells, it is possible to calculate a predicted value for tissue $\mathrm{NO}_{3}{ }^{-}$based on initial size of the tissue $\mathrm{NO}_{3}{ }^{-}$pool, $\mathrm{NR}$ activity and the rate of $\mathrm{NO}_{3}{ }^{-}$uptake. Predicted tissue $\mathrm{NO}_{3}{ }^{-}$values were calculated using the following equation:

$\begin{aligned} & \text { Predicted } \\ & \text { tissue } \mathrm{NO}_{3}{ }^{-}\end{aligned}=\begin{aligned} & \text { Tissue } \mathrm{NO}_{3}^{-} \text {initial } \\ & \cdot \text { time })+(\mathrm{NR} \text { activity }\end{aligned}$

where time is the elapsed time between the beginning and end of a time period, NR activity is the average of $\mathrm{NR}$ activity measured at the beginning and end of a time period, and $\mathrm{NO}_{3}{ }^{-}$uptake is the average of $\mathrm{NO}_{3}{ }^{-}$ uptake rate measured at the beginning and end of a time period. Since calculating a predicted tissue $\mathrm{NO}_{3}{ }^{-}$ requires a tissue $\mathrm{NO}_{3}{ }^{-}$initial, predicted tissue $\mathrm{NO}_{3}{ }^{-}$could only be calculated for points after time $0 \mathrm{~h}$. To determine whether the rates of $\mathrm{NO}_{3}^{-}$reduction and $\mathrm{NO}_{3}{ }^{-}$ uptake could explain the observed changes in tissue $\mathrm{NO}_{3}{ }^{-}$, the predicted tissue $\mathrm{NO}_{3}{ }^{-}$was compared with the measured tissue $\mathrm{NO}_{3}^{-}$. In calculating predicted 
tissue $\mathrm{NO}_{3}{ }^{-}$, techniques of error propagation were used to estimate error (Tsokos 1972).

Statistical analysis. All statistical comparisons were performed using SPSS Base 10.0 for Windows (SPSS) with the level of significance set at an $\alpha$ of 0.05 . Outliers were identified using the 'inter quartile range $x$ 1.5 rule' (Moore \& McCabe 1993). Differences over time between $\mathrm{NO}_{3}{ }^{-}$treatments were tested for significance using a univariate repeated-measures test with time as the within-subject factor, $\mathrm{NO}_{3}{ }^{-}$treatment as the between-subject factor, and $\mathrm{NR}$ activity, tissue $\mathrm{NO}_{3}^{-}$, tissue $\mathrm{NH}_{4}{ }^{+}, \mathrm{FAA}$, or $\mathrm{NO}_{3}{ }^{-}$uptake as the dependent variables (Winer et al. 1991). The normality of the data was tested using the Shapiro-Wilk test and the sphericity of the data using Mauchly's test for sphericity (Winer et al. 1991). When the sphericity assumption was not met, the Huynh-Feldt adjustment was employed (Zar 1999). Homogeneity of error variance was tested using Levene's test of equality of error variance (Sachs 1984). Data that failed Levene's test of equality of error variance were transformed. In the 2 cases where the transformed data still did not meet the assumption of equal error variance $\left(\mathrm{NO}_{3}{ }^{-}\right.$uptake during the 12 and $3 \mathrm{~h}$ experiments), a Kruskal-Wallis test was performed at each time point (Winer et al. 1991, Sokal \& Rohlf 1995). For dependent variables where the between-subject effect was significant and where there were more than $2 \mathrm{NO}_{3}{ }^{-}$treatments, the Tukey's honest significant difference (HSD) post-hoc test (parametric comparisons) or the Games-Howell posthoc test (non-parametric comparisons) was used to identify which $\mathrm{NO}_{3}{ }^{-}$treatments were significantly different (Winer et al. 1991). Linear regressions were also performed using SPSS Base 10.0 for Windows, while non-linear regressions were performed using Sigma Plot 6.0 (SPSS).

\section{RESULTS}

The total nitrogen content of Enteromorpha sp. prior to the start of the $\mathrm{NO}_{3}{ }^{-}$pulse experiments was $4.68 \pm$ $0.52 \%$ dry wt $(\mathrm{SE}, \mathrm{n}=15)$. Since tissue $\mathrm{NO}_{2}{ }^{-}$concentrations were consistently below $0.02 \mathrm{mmol} \mathrm{NO}_{2}^{-} \mathrm{g}^{-1}$ fresh $\mathrm{wt}$, they are not reported in further detail.

\section{Nitrate-pulse experiments (12 h)}

In the $30 \mu \mathrm{M} \mathrm{NO}_{3}{ }^{-}$treatment, $\mathrm{NO}_{3}{ }^{-}$uptake was highest $\left(9.09 \pm 2.63 \mu \mathrm{mol} \mathrm{NO}_{3}^{-} \mathrm{g}^{-1}\right.$ fresh wt $\left.\mathrm{h}^{-1}\right)$ when Enteromorpha sp. was initially exposed to $\mathrm{NO}_{3}^{-}(0 \mathrm{~h})$ (Fig. 1A). Again, this uptake rate represents the average uptake over the first $10 \mathrm{~min}$ of the experiment. Uptake declined over time as the tissue $\mathrm{NO}_{3}{ }^{-}$pool filled (Fig. 1B). Once the tissue $\mathrm{NO}_{3}{ }^{-}$pool appeared to be filled to capacity at $27.19 \pm 7.00 \mathrm{\mu mol} \mathrm{NO}_{3}{ }^{-} \mathrm{g}^{-1}$ fresh wt after $6 \mathrm{~h}$, the $\mathrm{NO}_{3}{ }^{-}$uptake rate remained at the low level of $\sim 0$ to $1.5 \mu \mathrm{mol} \mathrm{NO}_{3}^{-} \mathrm{g}^{-1}$ fresh wt $\mathrm{h}^{-1}$. Enteromorpha sp. in the control treatment $\left(0 \mu \mathrm{M} \mathrm{NO}{ }_{3}^{-}\right)$ showed no net $\mathrm{NO}_{3}{ }^{-}$uptake or release during the $12 \mathrm{~h}$ and no change in tissue $\mathrm{NO}_{3}{ }^{-}$over time. The difference in tissue $\mathrm{NO}_{3}^{-}$between treatments was significant (Table 1). The difference in $\mathrm{NO}_{3}{ }^{-}$uptake rate between treatments was only significant for tissue collected at Time 0 h (Table 2).

While $\mathrm{NO}_{3}^{-}$accumulated within Enteromorpha sp. exposed to $\mathrm{NO}_{3}{ }^{-}$, tissue $\mathrm{NH}_{4}{ }^{+}$did not change in either the control $\left(0 \mu \mathrm{M} \mathrm{NO}_{3}{ }^{-}\right)$or $30 \mu \mathrm{M} \mathrm{NO}{ }_{3}^{-}$treatment (Fig. 1C). There was no significant difference in tissue $\mathrm{NH}_{4}{ }^{+}$between treatments (Table 1). However, there was a significant difference in FAA between treatments (Table 1) with higher FAA in Enteromorpha sp. from the $30 \mu \mathrm{M} \mathrm{NO}_{3}{ }^{-}$treatment (Fig. 1D).

Overall, tissue $\mathrm{NO}_{3}{ }^{-}$was the predominant form of inorganic nitrogen within algal cells and was $6.5 \%$ of the total nitrogen content when the tissue $\mathrm{NO}_{3}{ }^{-}$pool was full. The tissue $\mathrm{NH}_{4}{ }^{+}$pool comprised a smaller portion $(<0.5 \%)$ of the total nitrogen content and not a significant store of inorganic nitrogen. The FAA pool (on average only $3 \%$ of the total nitrogen content) was not much larger than the tissue $\mathrm{NO}_{3}{ }^{-}$pool prior to $\mathrm{NO}_{3}{ }^{-}$ enrichment and, in fact, was smaller following $12 \mathrm{~h}$ at $30 \mathrm{MM} \mathrm{NO}_{3}^{-}$.

NR activity was still detected in Enteromorpha sp. after $24 \mathrm{~h}$ in the no $\mathrm{NO}_{3}{ }^{-}$pre-treatment, $0.17 \pm 0.04$ and $0.15 \pm 0.04 \mu \mathrm{mol} \mathrm{NO}{ }^{-} \mathrm{g}^{-1}$ fresh wt $\mathrm{h}^{-1}$ in the control $\left(0 \mu \mathrm{M} \mathrm{NO}_{3}^{-}\right)$and $30 \mu \mathrm{M} \mathrm{NO}_{3}^{-}$treatment, respectively (mean $\pm \mathrm{SE}$ ) (Fig. 1E). In the first $3 \mathrm{~h}$, NR activity increased 5-fold to $0.80 \pm 0.23 \mu \mathrm{mol} \mathrm{NO}{ }^{-} \mathrm{g}^{-1}$ fresh wt $\mathrm{h}^{-1}$ in the $30 \mu \mathrm{M} \mathrm{NO}{ }_{3}^{-}$treatment and remained at roughly that level for the duration of the experiment. This peak NR activity was approximately 10-fold less than the peak $\mathrm{NO}_{3}{ }^{-}$uptake rate (Fig. 1A,E). In the control treatment $\left(0 \mu \mathrm{M} \mathrm{NO}_{3}{ }^{-}\right), \mathrm{NR}$ activity increased only slightly over the $12 \mathrm{~h}$, never reaching higher than 0.29 $\pm 0.06 \mu \mathrm{mol} \mathrm{NO}{ }_{2}^{-} \mathrm{g}^{-1}$ fresh $\mathrm{wt} \mathrm{h}^{-1}$. The difference in NR activity between treatments was significant (Table 1).

\section{Nitrate pulse experiment $(3 \mathrm{~h})$}

In the $3 \mathrm{~h}$ experiment, uptake peaked or was near its peak in the 6 and $30 \mu \mathrm{M}$ treatments when Enteromorpha sp. was first exposed to $\mathrm{NO}_{3}{ }^{-}(0 \mathrm{~min})$ (Fig. 2A). Again, the reported uptake rates represent uptake over the 10 min following the time of tissue collection. Meanwhile, Enteromorpha sp. in the control treatment $\left(0 \mu \mathrm{M} \mathrm{NO}_{3}{ }^{-}\right)$showed no net $\mathrm{NO}_{3}{ }^{-}$uptake or release. The difference in $\mathrm{NO}_{3}^{-}$uptake rate between treat- 

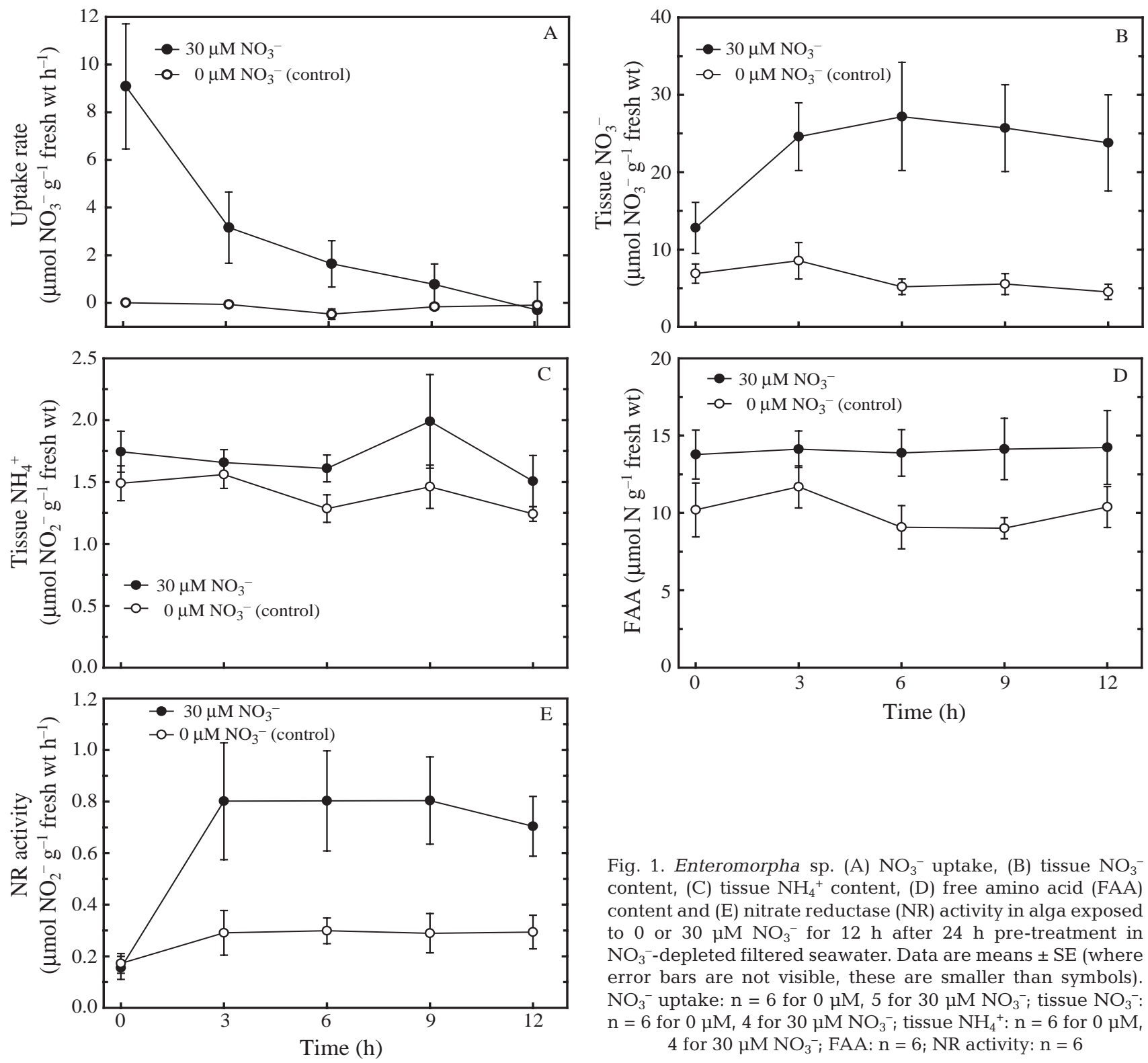

Fig. 1. Enteromorpha sp. (A) $\mathrm{NO}_{3}^{-}$uptake, (B) tissue $\mathrm{NO}_{3}{ }^{-}$ content, (C) tissue $\mathrm{NH}_{4}{ }^{+}$content, (D) free amino acid (FAA) content and (E) nitrate reductase (NR) activity in alga exposed to 0 or $30 \mu \mathrm{M} \mathrm{NO}_{3}^{-}$for $12 \mathrm{~h}$ after $24 \mathrm{~h}$ pre-treatment in $\mathrm{NO}_{3}{ }^{-}$-depleted filtered seawater. Data are means $\pm \mathrm{SE}$ (where error bars are not visible, these are smaller than symbols). $\mathrm{NO}_{3}{ }^{-}$uptake: $\mathrm{n}=6$ for $0 \mu \mathrm{M}, 5$ for $30 \mu \mathrm{M} \mathrm{NO}_{3}{ }^{-}$; tissue $\mathrm{NO}_{3}{ }^{-}$: $\mathrm{n}=6$ for $0 \mu \mathrm{M}, 4$ for $30 \mu \mathrm{M} \mathrm{NO}_{3}^{-}$; tissue $\mathrm{NH}_{4}^{+}: \mathrm{n}=6$ for $0 \mu \mathrm{M}$, 4 for $30 \mu \mathrm{M} \mathrm{NO}_{3}^{-}$; FAA: $\mathrm{n}=6$; $\mathrm{NR}$ activity: $\mathrm{n}=6$

Table 1. Enteromorpha sp. Results of repeated-measures ANOVA for 12 and $3 \mathrm{~h}$ pulse experiments. Significant values in bold. ${ }^{*} \mathrm{p} \leq 0.05 ;{ }^{* *} \mathrm{p} \leq 0.01{ }^{* * *} \mathrm{p} \leq 0.001$. FAA: free amino acids; NR: nitrate reductase

\begin{tabular}{|c|c|c|c|c|c|c|c|c|c|}
\hline \multirow[t]{2}{*}{ Dependent variable } & \multicolumn{3}{|c|}{ Time } & \multicolumn{3}{|c|}{$\mathrm{NO}_{3}{ }^{-}$treatment } & \multicolumn{3}{|c|}{ Time $\times \mathrm{NO}_{3}{ }^{-}$treatment } \\
\hline & df & $F$ & $\mathrm{p}$ & df & $F$ & $\mathrm{p}$ & $\mathrm{df}$ & $F$ & $\mathrm{p}$ \\
\hline \multicolumn{10}{|l|}{$12 \mathrm{~h}$ experiment } \\
\hline Tissue $\mathrm{NO}_{3}^{-}$ & 2.99 & 1.05 & 0.390 & 1 & 33.04 & $<0.001^{* * *}$ & 3.00 & 2.82 & 0.061 \\
\hline Tissue $\mathrm{NH}_{4}{ }^{+}$ & 2.15 & 1.54 & 0.237 & 1 & 3.87 & 0.078 & 2.15 & 0.33 & 0.737 \\
\hline FAA & 4.00 & 0.29 & 0.880 & 1 & 12.17 & $0.006^{* *}$ & 4.00 & 0.25 & 0.910 \\
\hline NR activity & 2.60 & 8.12 & $0.001^{* * *}$ & 1 & 4.96 & $0.050^{*}$ & 2.60 & 2.47 & 0.091 \\
\hline \multicolumn{10}{|l|}{$3 \mathrm{~h}$ experiment } \\
\hline Tissue $\mathrm{NO}_{3}^{-}$ & 4.99 & 5.06 & $<0.001^{* * *}$ & 2 & 39.80 & 0.092 & 9.99 & 1.21 & 0.298 \\
\hline Tissue $\mathrm{NH}_{4}^{+}$ & 5.00 & 2.97 & $0.016^{*}$ & 2 & 0.28 & 0.762 & 10 & 0.46 & 0.911 \\
\hline FAA & 5.00 & 1.56 & 0.183 & 2 & 0.52 & 0.605 & 10 & 1.07 & 0.400 \\
\hline NR activity & 3.27 & 12.99 & $<0.001^{* * *}$ & 2 & 3.86 & $0.041^{*}$ & 6.53 & 1.44 & 0.213 \\
\hline
\end{tabular}


ments was significant at each time point (Table 2). While $\mathrm{NO}_{3}{ }^{-}$uptake rate appeared higher in the $30 \mu \mathrm{M}$ treatment compared to the $6 \mu \mathrm{M} \mathrm{NO}{ }^{-}$treatment, Games-Howell post-hoc, pair-wise comparisons only found a significant difference between these $2 \mathrm{NO}_{3}{ }^{-}$ treatments for tissue collected at the 0 min mark.

Similar to the $12 \mathrm{~h}$ experiment, $\mathrm{NO}_{3}{ }^{-}$appeared to accumulate within Enteromorpha sp. exposed to $\mathrm{NO}_{3}{ }^{-}$during the $3 \mathrm{~h}$ experiment (Fig. 2B). However, the difference in tissue $\mathrm{NO}_{3}{ }^{-}$between treatments was not significant (Table 1). Much as in the $12 \mathrm{~h}$ experiment, tissue $\mathrm{NH}_{4}{ }^{+}$ did not differ between treatments (Table 1, Fig. 2C).
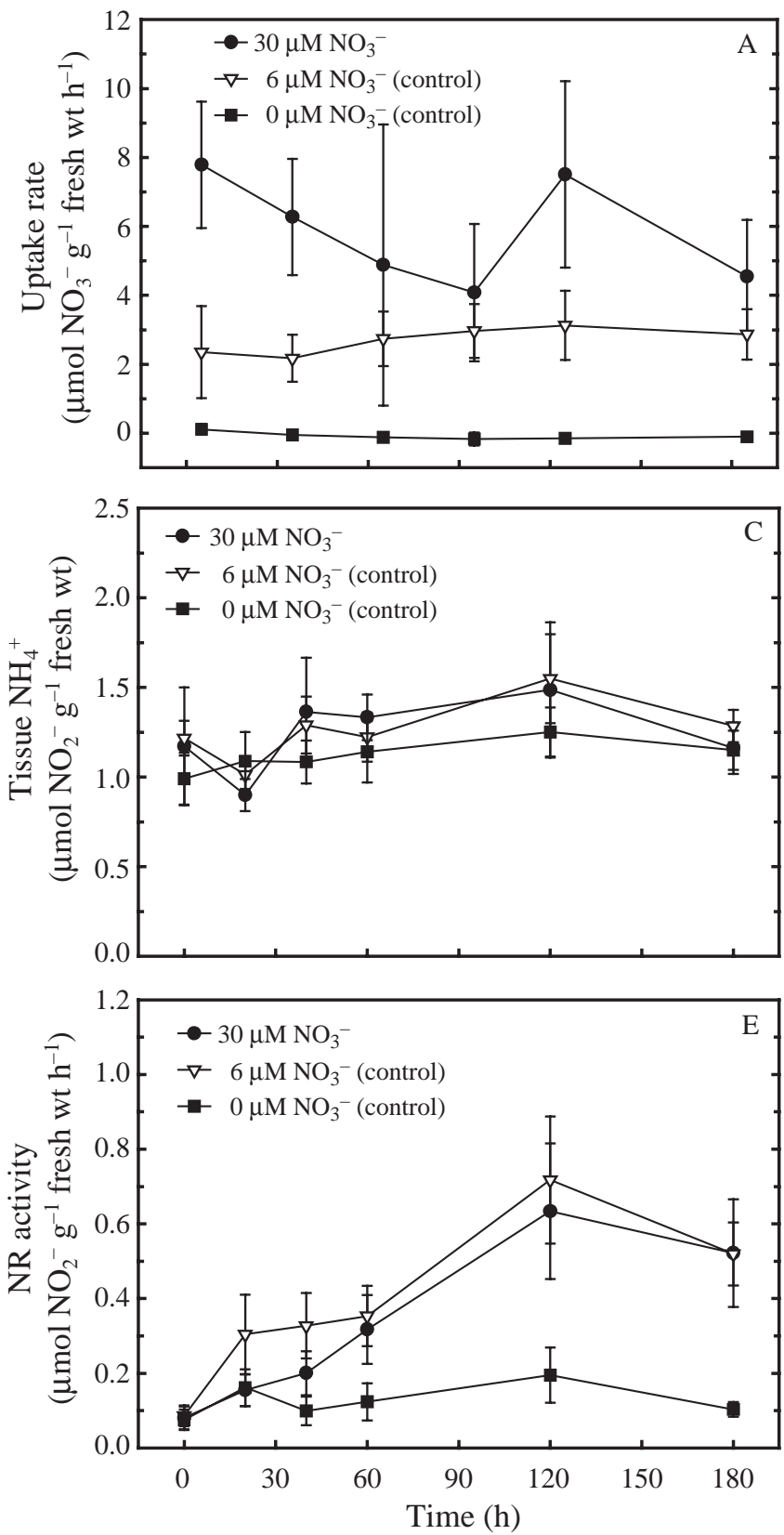

There was also no difference in FAA among the control $(0 \mu \mathrm{M}), 6$, and $30 \mu \mathrm{M} \mathrm{NO}_{3}{ }^{-}$treatments (Table 1, Fig. 2D).

Roughly 2 to $3 \mathrm{~h}$ elapsed between exposure to $\mathrm{NO}_{3}{ }^{-}$ and peak NR activity (Fig. 2E). Furthermore, a higher $\mathrm{NO}_{3}{ }^{-}$concentration did not result in a higher peak NR activity or peak activity being reached any sooner. While NR activity increased over time in the 6 and $30 \mu \mathrm{M} \mathrm{NO}_{3}{ }^{-}$treatments, it did not in the control treatment $\left(0 \mu \mathrm{M} \mathrm{NO}_{3}{ }^{-}\right)$. The difference in NR activity between treatments was significant (Table 1). However, Tukey's HSD post-hoc, pair-wise comparisons found only the control $\left(0 \mu \mathrm{M} \mathrm{NO}_{3}{ }^{-}\right)$and $6 \mu \mathrm{M} \mathrm{NO}_{3}{ }^{-}$
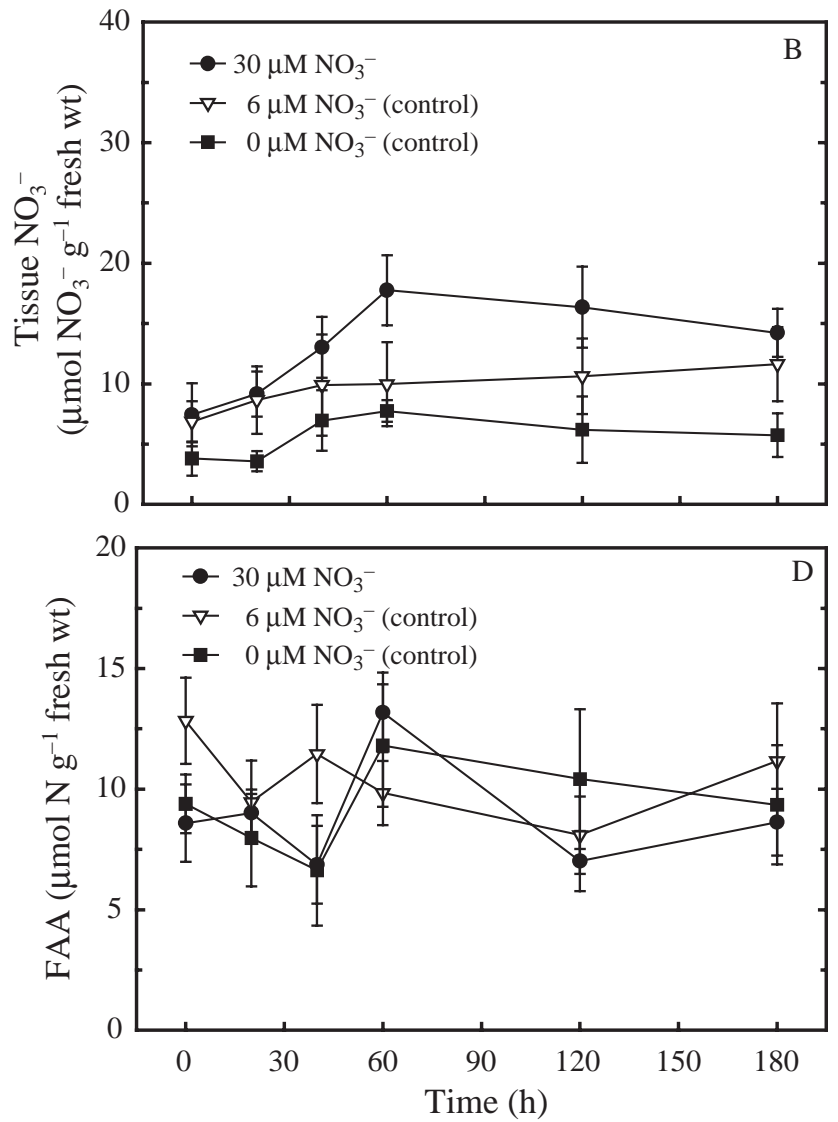

Fig. 2. Enteromorpha sp. (A) $\mathrm{NO}_{3}{ }^{-}$uptake, (B) tissue $\mathrm{NO}_{3}{ }^{-}$ content, (C) tissue $\mathrm{NH}_{4}{ }^{+}$content, (D) FAA content and (E) NR activity in alga exposed to 0 or $30 \mu \mathrm{M} \mathrm{NO}_{3}{ }^{-}$for $3 \mathrm{~h}$ after $24 \mathrm{~h}$ pre-treatment in $\mathrm{NO}_{3}{ }^{-}$-depleted filtered seawater. Data are mean $+\mathrm{SE}$ (where error bars are not visible, these are smaller than symbols). $\mathrm{NO}_{3}{ }^{-}$uptake: $\mathrm{n}=6$ for $0 \mu \mathrm{M}, 7$ for 6 and $30 \mu \mathrm{M}$ $\mathrm{NO}_{3}^{-}$; tissue $\mathrm{NO}_{3}^{-}: \mathrm{n}=4$ for $0 \mu \mathrm{M}, 7$ for 6 and $30 \mu \mathrm{M} \mathrm{NO}_{3}{ }^{-}$; tissue $\mathrm{NH}_{4}^{+}: \mathrm{n}=6$ for $0 \mu \mathrm{M}, 7$ for 6 and $30 \mu \mathrm{M} \mathrm{NO}_{3}^{-}$; FAA: $\mathrm{n}=6$ for $0 \mu \mathrm{M}, 5$ for 6 and $30 \mu \mathrm{M} \mathrm{NO}_{3}{ }^{-}$; NR activity: $\mathrm{n}=4$ for $0 \mu \mathrm{M}$, 5 for 6 and $30 \mu \mathrm{M} \mathrm{NO}_{3}{ }^{-}$. Abbreviations as in Fig. 1 
Table 2. Enteromorpha sp. Results of Kruskal-Wallis test of $\mathrm{NO}_{3}{ }^{-}$uptake at each time point during 12 and $3 \mathrm{~h}$ pulse experiments. Significant values in bold. ${ }^{*} p \leq 0.05 ;{ }^{* *} p \leq 0.01$

\begin{tabular}{|llcc|}
\hline Time & df & $\chi^{2}$ & $\mathrm{p}$ \\
\hline $\mathbf{1 2}$ h experiment & & & \\
$0 \mathrm{~h}$ & 1 & 7.50 & $\mathbf{0 . 0 0 6}^{*}$ \\
$3 \mathrm{~h}$ & 1 & 0.92 & 0.337 \\
$6 \mathrm{~h}$ & 1 & 3.69 & 0.055 \\
$9 \mathrm{~h}$ & 1 & 0.93 & 0.336 \\
$12 \mathrm{~h}$ & 1 & 0.03 & 0.873 \\
& & & \\
$\mathbf{3}$ h experiment & & & \\
0 min & 2 & 9.85 & $\mathbf{0 . 0 0 7}^{* *}$ \\
20 min & 2 & 11.58 & $\mathbf{0 . 0 0 3}^{* *}$ \\
40 min & 2 & 8.05 & $\mathbf{0 . 0 1 8}^{*}$ \\
60 min & 2 & 7.64 & $\mathbf{0 . 0 2 2}^{*}$ \\
120 min & 2 & 9.99 & $\mathbf{0 . 0 0 7}^{* *}$ \\
180 min & 2 & 7.42 & $\mathbf{0 . 0 2 4}^{*}$ \\
\hline
\end{tabular}

treatments distinct from each other $(\mathrm{p}=0.034)$, with no significant difference between the 6 and $30 \mu \mathrm{M} \mathrm{NO}_{3}^{-}$ treatments $(\mathrm{p}=0.532)$.

The first $3 \mathrm{~h}$ of the $12 \mathrm{~h}$ and the $3 \mathrm{~h}$ experiments were similar in peak $\mathrm{NO}_{3}^{-}$uptake rate, peak NR activity, tissue $\mathrm{NH}_{4}{ }^{+}$and the size of the FAA pool, but showed differences in initial NR activity and tissue $\mathrm{NO}_{3}^{-}$both initially and after $3 \mathrm{~h}$. The differences suggest different conditions in the field when Enteromorpha sp. was collected for each experiment, which is not surprising since the 12 and $3 \mathrm{~h}$ experiments were conducted a year apart. However, the response of Enteromorpha sp. to the $30 \mu \mathrm{M} \mathrm{NO}_{3}{ }^{-}$pulse in each experiment was similar: a sudden peak and then decline in uptake, filling of the internal $\mathrm{NO}_{3}{ }^{-}$pool, an increase in NR activity, and consistent size of the internal $\mathrm{NH}_{4}{ }^{+}$and FAA pools over time.

\section{Nitrate balance calculations}

The error estimates overlap for the predicted tissue $\mathrm{NO}_{3}{ }^{-}$and the measured tissue $\mathrm{NO}_{3}{ }^{-}$in all 8 cases for the $12 \mathrm{~h}$ pulse experiment and in 12 of the 15 cases for the $3 \mathrm{~h}$ pulse experiment (Table 3 ). In 2 of the 3 cases during the $3 \mathrm{~h}$ pulse experiment where the error estimates do not overlap $(0 \mu \mathrm{M}, 40 \mathrm{~min}$ and $30 \mu \mathrm{M}$, $120 \mathrm{~min})$, the error estimates are less than $0.15 \mu \mathrm{mol}$ $\mathrm{g}^{-1}$ fresh wt from overlapping. This strong agreement between the predicted and measured tissue $\mathrm{NO}_{3}{ }^{-}$ holds for both the control $\left(0 \mu \mathrm{M} \mathrm{NO}_{3}{ }^{-}\right)$and experimental $\left(6\right.$ and $\left.30 \mu \mathrm{M} \mathrm{NO}_{3}{ }^{-}\right)$treatments.

The use of Eq. (1) to calculate predicted changes in tissue $\mathrm{NO}_{3}{ }^{-}$requires the assumption that the change in $\mathrm{NO}_{3}{ }^{-}$uptake and NR activity between successive points is linear. This assumption appears reasonable for NR activity during both the 12 and $3 \mathrm{~h}$ experiments, $\mathrm{NO}_{3}{ }^{-}$ uptake in the controls $\left(0 \mu \mathrm{M} \mathrm{NO}_{3}{ }^{-}\right)$in both the 12 and $3 \mathrm{~h}$ experiments, and the $6 \mu \mathrm{M} \mathrm{NO}_{3}{ }^{-}$treatment in the $3 \mathrm{~h}$ experiment. While the change in $\mathrm{NO}_{3}{ }^{-}$uptake over time in the $30 \mu \mathrm{M} \mathrm{NO}_{3}{ }^{-}$treatment in both the 12 and $3 \mathrm{~h}$ experiments does not appear to be linear over the entire experiments, assuming that the change between successive points is linear is reasonable. For example, fitting an exponential decay function to uptake in the $30 \mathrm{MM} \mathrm{NO}_{3}{ }^{-}$treatment during the $12 \mathrm{~h}$ experiment produces a significant regression $\left(y=9.04 \exp ^{-0.32 x}\right.$, adj$\left.\mathrm{R}^{2}=0.99, F=317.08, \mathrm{p}=0.0004\right)$ that describes more of the variation in uptake than a linear function $(y=$ $-0.71 x+7.10$, adj $\left.-\mathrm{R}^{2}=0.76, F=13.55, \mathrm{p}=0.035\right)$. How ever, between successive points the area under the curve for the exponential decay function is similar to the area under the curve assuming a linear change between successive points. For the 0 to 3,3 to 6,6 to 9 and 9 to $12 \mathrm{~h}$ intervals the exponential decay function predicts $17.43,6.68,2.55$, and $0.98 \mu \mathrm{mol} \mathrm{NO}{ }_{3}^{-} \mathrm{g}^{-1}$ fresh wt being taken up, respectively, while assuming a lin-

Table 3. Enteromorpha sp. Comparison of predicted with measured tissue $\mathrm{NO}_{3}^{-}\left(\mu \mathrm{mol} \mathrm{g}{ }^{-1}\right.$ fresh $\mathrm{wt}_{\text {, }}$ mean $\left.\pm \mathrm{SE}\right)$ in $12 \mathrm{~h}$ and $3 \mathrm{~h}$ pulse experiments. ${ }^{*}$ : predicted and measured tissue $\mathrm{NO}_{3}{ }^{-}$error estimates overlap

\begin{tabular}{|c|c|c|}
\hline Time & Predicted & Measured \\
\hline \multicolumn{3}{|c|}{$12 \mathrm{~h} \mathrm{NO}_{3}{ }^{-}$pulse experiment } \\
\hline \multicolumn{3}{|c|}{$0 \mu \mathrm{M} \mathrm{NO}_{3}^{-}$treatment } \\
\hline $3 \mathrm{~h}^{*}$ & $6.10 \pm 1.26$ & $8.54 \pm 2.37$ \\
\hline $6 \mathrm{~h}^{*}$ & $6.85 \pm 2.40$ & $5.18 \pm 1.00$ \\
\hline $9 \mathrm{~h}^{*}$ & $3.35 \pm 1.08$ & $5.53 \pm 1.35$ \\
\hline $12 \mathrm{~h}^{*}$ & $4.27 \pm 1.38$ & $4.52 \pm 0.98$ \\
\hline \multicolumn{3}{|c|}{$30 \mathrm{\mu M} \mathrm{NO}_{3}{ }^{-}$treatment } \\
\hline $3 \mathrm{~h}^{*}$ & $29.73 \pm 5.62$ & $24.59 \pm 4.38$ \\
\hline $6 \mathrm{~h}^{*}$ & $29.38 \pm 5.16$ & $27.18 \pm 7.00$ \\
\hline $9 \mathrm{~h}^{*}$ & $28.40 \pm 7.27$ & $25.69 \pm 5.61$ \\
\hline $12 \mathrm{~h}^{*}$ & $24.14 \pm 6.04$ & $23.78 \pm 6.21$ \\
\hline \multicolumn{3}{|c|}{$3 \mathrm{~h} \mathrm{NO}{ }^{-}$pulse experiment } \\
\hline \multicolumn{3}{|c|}{$0 \mu \mathrm{M} \mathrm{NO}_{3}^{-}$treatment } \\
\hline $20 \min ^{*}$ & $3.77 \pm 1.42$ & $3.57 \pm 0.83$ \\
\hline $40 \min$ & $3.50 \pm 0.83$ & $6.95 \pm 2.50$ \\
\hline $60 \min ^{*}$ & $6.87 \pm 2.50$ & $7.74 \pm 0.89$ \\
\hline $120 \min ^{*}$ & $7.42 \pm 0.90$ & $6.19 \pm 2.75$ \\
\hline $180 \min ^{*}$ & $5.92 \pm 2.75$ & $5.73 \pm 1.80$ \\
\hline \multicolumn{3}{|c|}{$6 \mu \mathrm{M} \mathrm{NO}_{3}{ }^{-}$treatment } \\
\hline $20 \min ^{*}$ & $7.55 \pm 1.72$ & $8.65 \pm 2.79$ \\
\hline $40 \min ^{*}$ & $9.37 \pm 2.80$ & $9.89 \pm 4.21$ \\
\hline $60 \min ^{*}$ & $10.73 \pm 4.21$ & $9.97 \pm 3.47$ \\
\hline $120 \min ^{*}$ & $12.48 \pm 3.53$ & $10.63 \pm 3.14$ \\
\hline $180 \min ^{*}$ & $13.01 \pm 3.21$ & $11.62 \pm 3.08$ \\
\hline \multicolumn{3}{|c|}{$30 \mathrm{\mu M} \mathrm{NO}_{3}{ }^{-}$treatment } \\
\hline $20 \min ^{*}$ & $9.73 \pm 2.64$ & $9.15 \pm 1.87$ \\
\hline $40 \min ^{*}$ & $10.95 \pm 2.01$ & $13.02 \pm 2.51$ \\
\hline $60 \min ^{*}$ & $14.43 \pm 2.62$ & $17.76 \pm 2.89$ \\
\hline $120 \min$ & $23.08 \pm 3.34$ & $16.35 \pm 3.36$ \\
\hline $180 \min$ & $21.80 \pm 3.72$ & $14.22 \pm 1.99$ \\
\hline
\end{tabular}


ear change between successive points leads to 18.38 , $7.20,3.98,0.73 \mu \mathrm{mol} \mathrm{NO}{ }^{-} \mathrm{g}^{-1}$ fresh wt being taken up in the same intervals. It is worth noting that of the $30.20 \mu \mathrm{mol} \mathrm{NO}{ }_{3}^{-}$taken up $\mathrm{g}^{-1}$ fresh wt calculated using the latter approach, $18.38 \mu \mathrm{mol} \mathrm{NO}_{3}{ }^{-}$or $60.68 \%$ of the total was taken up in the first $3 \mathrm{~h}$ and $25.58 \mu \mathrm{mol} \mathrm{\textrm {NO } _ { 3 }}{ }^{-}$ or $84.45 \%$ of the total in the first $6 \mathrm{~h}$.

\section{DISCUSSION}

Estuarine Enteromorpha sp. can take up transient $\mathrm{NO}_{3}{ }^{-}$pulses, but $\mathrm{NO}_{3}{ }^{-}$reduction by NR ultimately limits the amount of pulse-derived nitrogen that is accumulated in the macroalga. When $\mathrm{NO}_{3}{ }^{-}$suddenly becomes available to Enteromorpha sp., uptake begins and peak uptake occurs within $10 \mathrm{~min}$ if not sooner. While there is a background level of NR activity, this level of activity is insufficient to empty the tissue $\mathrm{NO}_{3}{ }^{-}$ pool as quickly as it is being filled. Even when NR is fully induced and activated after 2 to $3 \mathrm{~h}$, NR activity is still insufficient. While at lower $\mathrm{NO}_{3}{ }^{-}$concentrations the discrepancy is less because of the concentration dependence of $\mathrm{NO}_{3}{ }^{-}$uptake (Pedersen \& Borum 1997), peak $\mathrm{NO}_{3}{ }^{-}$uptake rate at low $\mathrm{NO}_{3}{ }^{-}$concentrations (e.g. $6 \mu \mathrm{M}$ ) is still at least 2- to 3-fold higher than peak NR activity. As a result, once the tissue $\mathrm{NO}_{3}{ }^{-}$pool reaches capacity, the rate of $\mathrm{NO}_{3}{ }^{-}$uptake becomes equal to or less than the rate of $\mathrm{NO}_{3}{ }^{-}$reduction. While the size of the tissue $\mathrm{NO}_{3}{ }^{-}$pool increases, the size of the tissue ammonium $\mathrm{NH}_{4}{ }^{+}$and FAA pools remain roughly constant, further suggesting that the reduction of $\mathrm{NO}_{3}{ }^{-}$to $\mathrm{NO}_{2}{ }^{-}$by $\mathrm{NR}$ is rate-limiting.

There is the possibility that low trace metal concentrations may have existed in the field at the time of collection (Lewitus et al. 2004) or in the pre-treatment and treatment seawater, leading to trace metal limitation in Enteromorpha sp. Since NR contains a heme-iron prosthetic group as well as a molybdopterin cofactor (Crawford \& Campbell 1990), iron or molybdenum limitation could impact the response of Enteromorpha sp. to a $\mathrm{NO}_{3}{ }^{-}$pulse. In fact, iron limitation has been shown to decrease NR activity in several species of phytoplankton (Timmermans et al. 1994, Milligan \& Harrison 2000). Similarly, phosphorus availability may have been low as well. Water column phosphate and the phosphorus content of Enteromorpha sp. were not measured; however, the dissolved inorganic nitrogen to phosphate ratio in the lower estuary where the Enteromorpha sp. was collected is historically $\sim 10$, suggesting that the alga was more likely to be nitrogen rather phosphorus limited (Pennock et al. 1999). The similar response to a $\mathrm{NO}_{3}{ }^{-}$pulse in the 12 and $3 \mathrm{~h}$ experiments which were conducted a year apart suggests that the response observed in this study is probably common for Enteromorpha sp. in this estuary in the spring.

While the findings of this study agree with some of the work done by other investigators on the relationship between $\mathrm{NO}_{3}{ }^{-}$uptake, $\mathrm{NR}$ activity and tissue $\mathrm{NO}_{3}{ }^{-}$ in macroalgae, there is not complete agreement. Thomas \& Harrison (1985) also found that a low level of NR activity was maintained in Porphyra perforata following nitrogen starvation, but they reported an increase in NR activity over the first $3 \mathrm{~d}$ of nitrogen starvation before a rapid decline to a low level, which was not the case with Enteromorpha sp. in this study. Similar to our findings, Hwang et al. (1987) found that in Gracilaria tikvahiae the rate at which the tissue $\mathrm{NO}_{3}{ }^{-}$ pool was filled was concentration dependent and that the calculated rate of $\mathrm{NO}_{3}{ }^{-}$reduction was less than the $\mathrm{NO}_{3}{ }^{-}$uptake rate. In addition, Hwang et al. (1987) found that $\mathrm{NO}_{3}{ }^{-}$uptake was inhibited when tissue $\mathrm{NO}_{3}{ }^{-}$ was high. The findings of this study are similar to those of McGlathery et al. (1996) for Chaetomorpha linum as well. McGlathery et al. (1996) found that the maximum $\mathrm{NO}_{3}{ }^{-}$uptake rate appeared to be controlled by changes in small intracellular nitrogen pools, and also that when nitrogen starvation results in the emptying of inorganic nitrogen pools, $\mathrm{NO}_{3}{ }^{-}$uptake increases even if total nitrogen remains high. Furthermore, McGlathery et al. (1996) found that when nitrogen was available at saturating concentrations, the rate at which nitrogen pools filled was 2 -fold greater than the rate at which these pools were depleted when nitrogen became limiting. This relationship was present in the present study and in that of Hwang et al. (1987) as well.

The presence or absence of $\mathrm{NO}_{3}^{-}$in the water column rather than the size of the internal $\mathrm{NO}_{3}{ }^{-}$pool appears to determine the level of NR activity in Enteromorpha sp. The reduction of $\mathrm{NO}_{3}{ }^{-}$is energetically expensive (Crawford \& Arst 1993) and has been estimated to use as much as one-third of the photosynthetically produced reduction capacity in phytoplankton (Syrett 1981). Regulating NR activity based on the availability of external $\mathrm{NO}_{3}{ }^{-}$allows a greater proportion of a $\mathrm{NO}_{3}{ }^{-}$pulse to be utilized. Once $\mathrm{NO}_{3}{ }^{-}$is stored internally, its reduction need not be rapid, unless the internal $\mathrm{NO}_{3}{ }^{-}$pool is filled and additional $\mathrm{NO}_{3}{ }^{-}$is present in the water column. Once $\mathrm{NO}_{3}{ }^{-}$is no longer available in the water column, the failure to rapidly empty the internal $\mathrm{NO}_{3}{ }^{-}$pool no longer has an associated cost. At the background level of NR activity measured at the end of the no $\mathrm{NO}_{3}{ }^{-}$pre-treatment $\left(\sim 0.15 \mu \mathrm{mol} \mathrm{NO}{ }^{-}{ }^{-1}\right.$ fresh $\mathrm{wt} \mathrm{h}^{-1}$ ), it would take roughly $7.6 \mathrm{~d}$ to completely reduce an internal $\mathrm{NO}_{3}{ }^{-}$pool of $27.19 \mu \mathrm{mol} \mathrm{NO}_{3}{ }^{-} \mathrm{g}^{-1}$ fresh wt (the highest measured tissue $\mathrm{NO}_{3}{ }^{-}$). For comparison, the internal $\mathrm{NO}_{3}{ }^{-}$pools of Laminaria spp. and Macrocystis spp. would be fully reduced over a period of 2 to $3 \mathrm{wk}$ if nitrate reductase were active (Wheeler \& 
Srivastava 1984) or 5 to $6 \mathrm{wk}$ if the background level of $\mathrm{NR}$ activity were matched with the peak tissue $\mathrm{NO}_{3}{ }^{-}$ (Davison et al. 1984). In general, the rapid turnover of the nitrogen pool in ephemeral macroalgae such as Enteromorpha sp. and Ulva sp. suggests that the capacity to rapidly taken up and metabolize transient pulses of nutrients may be essential to their success (Aguiar et al. 2003). Considering the way in which $\mathrm{NO}_{3}{ }^{-}$is supplied to the Mobile Bay estuary (Pennock et al. 1999), transient pulses may play a large role in meeting the nitrogen demands of Enteromorpha sp. growing in the estuary.

The contribution of Enteromorpha sp. to the retention of $\mathrm{a} \mathrm{NO}_{3}{ }^{-}$pulse within an estuary would appear to occur within the initial hours of a pulse. In this study, during a $30 \mu \mathrm{M} \mathrm{NO}_{3}^{-}$pulse, roughly $85 \%$ of the total removal of $\mathrm{NO}_{3}{ }^{-}$from the water column by Enteromorpha sp. occurred in the first $6 \mathrm{~h}$ and the capacity to take up more $\mathrm{NO}_{3}{ }^{-}$appeared to remain at $\sim 1 \mu \mathrm{mol} \mathrm{NO}{ }_{3}^{-} \mathrm{g}^{-1}$ fresh wt $\mathrm{h}^{-1}$ beyond that point. Consequently, the impact of a pulse on Enteromorpha sp. is likely to be similar whether the pulse is $6 \mathrm{~h}$ in duration or much longer. In addition, in small embayments or coves with localized runoff and dense stands of ephemeral macroalgae, large amounts of $\mathrm{NO}_{3}{ }^{-}$may not become available downstream of macroalgal stands until hours after the initial pulse.

Our conclusions regarding the relationship between $\mathrm{NO}_{3}{ }^{-}$uptake, tissue $\mathrm{NO}_{3}{ }^{-}$and $\mathrm{NR}$ activity are only robust if our measurements of each quantitatively relate to each other. During both the 12 and $3 \mathrm{~h} \mathrm{NO}_{3}{ }^{-}$ pulse experiments there was overlap between the predicted and measured tissue $\mathrm{NO}_{3}{ }^{-}$values, suggesting that there is indeed agreement between the 3 measures. This agreement indicates that the methods used were measuring rates that reflected the actual uptake and reduction rates inside the alga and that the tissue $\mathrm{NO}_{3}{ }^{-}$extraction process was complete.

The larger $\mathrm{NO}_{3}{ }^{-}$pulses in the Mobile Bay estuary occur when $\mathrm{NO}_{3}{ }^{-}$-rich runoff, driven by winds, rapidly moves through the estuary. As a result, these $\mathrm{NO}_{3}{ }^{-}$ pulses are associated with declines in salinity and, due to sediment resuspension, decreases in irradiance and increases in water-column $\mathrm{NH}_{4}{ }^{+}$concentration. To understand the extent to which $\mathrm{NO}_{3}{ }^{-}$pulses are utilized by Enteromorpha sp., it will be necessary to test how changes in salinity, irradiance and water-column $\mathrm{NH}_{4}{ }^{+}$concentration impact the $\mathrm{NO}_{3}{ }^{-}$pulse response observed in this study. Work by Lartigue et al. (2003) on a closely related macroalga from the estuary, Ulva lactuca, suggests that $\mathrm{NO}_{3}{ }^{-}$uptake, at least, may be unaffected by changes in salinity (Hayden et al. 2003).

While the capacity of Enteromorpha sp. to take up and store pulsed $\mathrm{NO}_{3}{ }^{-}$in the short-term was investigated, the impact of the $\mathrm{NO}_{3}{ }^{-}$pulse on growth rate was not. However, long-term studies have shown that Enteromorpha sp. can use a pulsed nutrient supply to support growth (Björnsäter \& Wheeler 1990, Fong et al. 2004). Interestingly, Fong et al. (2004) have shown that dissolved organic nitrogen release following pulsed nutrient enrichment led to less than $100 \%$ net nitrogen retention in $E$. intestinalis, with the lowest percentage retention (roughly 72 to $80 \%$ ) occurring when pulses were either very high or low. As a result, any calculations of the impact of the $\mathrm{NO}_{3}{ }^{-}$taken up in this study on future growth may need to be adjusted downward to account for the possibility of less than $100 \%$ retention of pulse-derived nitrogen.

Differences in maximum uptake rate $\left(V_{\max }\right)$ and halfsaturation constant $\left(K_{\mathrm{s}}\right)$ between $r$ - and $K$-selected macroalgae as well as surface area-to-volume ratios have been able explain much of the success of ephemeral macroalgae in nutrient-enriched estuaries (see review by Raven \& Taylor 2003). Our finding that $\mathrm{NR}$ activity ultimately limits the amount of $\mathrm{NO}_{3}{ }^{-}$taken up during a $\mathrm{NO}_{3}{ }^{-}$pulse in Enteromorpha sp. suggests that, if patterns of NR synthesis and activation also differ between $r$ - and $K$-selected macroalgae, macroalgal distribution in estuaries may be further explained by species-specific differences in the enzymatic response to nutrient pulses.

Acknowledgements. We would like to thank the Dauphin Island Sea Lab, J. F. Valentine, and the University of South Alabama's Departments of Biology and Pharmacology for the use of equipment and facilities. Special thanks belong to J. L. W. Cowan and L. J. Linn for their help with the autoanalyzer. This work was funded by a Mississippi-Alabama Seagrant Consortium Marine Science Scholars Award (Project \# E/O16-Lartigue) and NSF award IBN-0105081. During the course of this study, J.L. was supported by graduate fellowships from the University of South Alabama's Department of Marine Sciences and the Dauphin Island Sea Lab. The comments offered by J. Cebrian, R. P. Kiene, P. A. Wheeler, and 4 anonymous reviewers were helpful in revising this manuscript.

\section{LITERATURE CITED}

Aguiar AB, Morgan JA, Teichberg M, Fox S, Valiela I (2003) Transplantation and isotopic evidence of the relative effects of ambient and internal nutrient supply on the growth of Ulva lactuca. Biol Bull (Woods Hole) 205: $250-251$

Berges JA (1997) Algal nitrate reductases. Eur J Phycol 32: $3-8$

Berges JA, Harrison PJ (1995) Relationships between nitrate reductase activity and rates of growth and nitrate incorporation under steady-state light nitrate limitation in the marine diatom Thalassiosira pseudonana (Bacillariophyceae). J Phycol 31:85-95

Björnsäter BR, Wheeler PA (1990) Effect of nitrogen and phosphorus supply on growth and tissue composition of Ulva fenestrata and Enteromorpha intestinalis (Ulvales, Chlorophyta). J Phycol 26:603-611

Chapman ARO, Craige JS (1977) Seasonal growth in Lami- 
naria longicruris: relations with dissolved inorganic nutrients and internal reserves of nitrogen. Mar Biol 40:197-205

Corzo A, Neill FX (1992) Blue light induction of in situ nitrate reductase activity in the marine green alga Ulva rigida. Aust J Plant Physiol 19:625-635

Crawford NM (1995) Nitrate: nutrient and signal for plant growth. Plant Cell 7:859-868

Crawford NM, Arst HNJ (1993) The molecular genetics of nitrate assimilation in fungi and plants. Annu Rev Genet 27:115-146

Crawford NM, Campbell WH (1990) Fertile fields. Plant Cell 2:829-835

Davison IR, Andrews M, Stewart WDP (1984) Regulation of growth in Laminaria digitata: use of in-vivo nitrate reductase activities as an indicator of nitrogen limitation in field populations of Laminaria spp. Mar Biol 84:207-217

Duke CS, Litaker RW, Ramus J (1987) Seasonal variation in RuBPCase activity and $\mathrm{N}$ allocation on the chlorophyte seaweeds Ulva curvata (Kutz.) De Toni and Codium decorticatum (Woodw.) Howe. J Exp Mar Biol Ecol 112:145-164

Fletcher RL (1996) The occurrence of 'green tides' - a review. In: Schra W, Nienhhuis PH (eds) Marine benthic vegetation: recent changes and the effects of eutrophication. Springer-Verlag, Berlin, p 7-43

Flindt MR, Kamp-Nielsen L, Marques JC, Pardal MA and 5 others (1997) Description of the three shallow estuaries: Mondego River (Portugal), Roskilde Fjord (Denmark) and the Lagoon of Venice (Italy). Ecol Model 102:17-31

Fong P, Zedler JB, Donohoe RM (1993) Nitrogen vs. phosphorous limitation of algal biomass in shallow coastal lagoons. Limnol Oceanogr 38:906-923

Fong P, Donohoe RM, Zedler JB (1994) Nutrient concentration in tissue of the macroalga Enteromorpha as a function of nutrient history: an experimental evaluation using field microcosms. Mar Ecol Prog Ser 106:273-281

Fong P, Fong JJ, Fong CR (2004) Growth, nutrient storage, and release of dissolved organic nitrogen by Enteromorpha intestinalis in response to pulses of nitrogen and phosphorus. Aquat Bot 78:83-95

Fujita RM, Wheeler PA, Edwards RL (1989) Assessment of macroalgal nitrogen limitation in a seasonal upwelling region. Mar Ecol Prog Ser 53:293-303

Harlin MM (1978) Nitrate uptake by Enteromorpha spp. (Chlorophyceae): applications to aquaculture systems. Aquaculture 15:373-376

Hayden HS, Blomster J, Maggs CA, Silva PC, Stanhope MJ, Waaland RJ (2003) Linnaeus was right all along: Ulva and Enteromorpha are not distinct genera. Eur J Phycol 38: 277-294

Hernandez I, Peralta G, Perez-Llorens JL, Vergara JJ, Niell FX (1997) Biomass and dynamics of growth of Ulva species in Palmones River estuary. J Phycol 33:764-772

Huber JL, Huber SC, Campbell WH, Redinbaugh MG (1992) Reversible light/dark modulation of spinach leaf nitrate reductase activity involves protein phosphorylation. Arch Biochem Biophys 296:58-65

Hwang SPL, Williams SL, Brinkhuis BH (1987) Changes in internal dissolved nitrogen pools as related to nitrate uptake and assimilation in Gracilaria tikvahiae McLacklan (Rhodophyta). Bot Mar 30:11-19

Kudo I, Miyamoto M, Noiri Y, Maita Y (2000) Combined effects of temperature and iron on the growth and physiology of the marine diatom Phaeodactylum tricornutum (Bacollariophyceae). J Phycol 36:1096-1102

Lapointe BE, Littler MM, Littler DM (1992) Nutrient availability to marine macroalgae in siliciclastic versus carbonaterich coastal waters. Estuaries 15:75-82
Lartigue J (2003) Nitrate uptake, nitrogen storage, and nitrate reductase activity in estuarine Enteromorpha sp. (Chlorophyceae). PhD dissertation, University of South Alabama, Mobile

Lartigue J, Sherman TD (2002) Field assays for measuring nitrate reductase activity in Enteromorpha sp. (Chlorophyceae), Ulva sp. (Chlorophyceae) and Gelidium sp. (Rhodophyceae). J Phycol 38:971-982

Lartigue J, Neill A, Hayden BL, Pulfer J, Cebrian (2003) The impact of salinity fluctuations on net oxygen production and inorganic nitrogen uptake by Ulva lactuca (Chlorophyceae). Aquat Bot 75:339-350

Lewitus AJ, Kawaguchi T, DiTullio GR, Keesee JDM (2004) Iron limitation of phytoplankton in an urbanized vs. forested southeastern U.S. salt marsh estuary. J Exp Mar Biol Ecol 298:233-254

Lopes PF, Oliveira MC, Colepicolo P (1997) Diurnal fluctuation of nitrate reductase activity in the marine red alga Gracilaria tenuistipitata (Rhodophyta). J Phycol 33: 225-231

Martins I, Pardal M (2001) Hydrodynamics as a major factor controlling the occurrence of green macroalgal blooms in a eutrophic estuary: a case study on the influence of precipitation and river management. Estuar Coast Shelf Sci 52:165-177

McGlathery KJ, Pedersen MF, Borum J (1996) Changes in intracellular nitrogen pools and feedback controls on nitrogen uptake in Chaetomorpha linum (Chlorophyta). J Phycol 32:393-401

Milligan AJ, Harrison PJ (2000) Effects of non-steady-state iron limitation on nitrogen assimilatory enzymes in the marine diatom Thalassiosira weissflogii (Bacillariophyceae). J Phycol 36:78-86

Moore DS, McCabe GP (1993) Introduction to the practice of statistics, 2nd edn. WH Freeman \& Company, New York

Naldi M, Viaroli P (2002) Nitrate uptake and storage in the seaweed Ulva rigida C. Agardh in relation to nitrate availability and thallus nitrate content in a eutrophic coastal lagoon (Sacca di Goro, Po River Delta, Italy). J Exp Mar Biol Ecol 269:65-83

Nixon SW, Pilson MEQ (1983) Nitrogen in estuarine and coastal marine ecosystems. In: Carpenter EJ, Capone DG (eds) Nitrogen in the marine environment. Academic Press, New York, p 565-648

Parsons TR, Maita Y, Lalli CM (1984) A manual of chemical and biological methods for seawater analysis, 1st edn. Pergamon Press, New York

Peckol P, Rivers JS (1996) Contribution by macroalgal mats to primary production of a shallow embayment under high and low nitrogen-loading rates. Estuar Coast Shelf Sci 43: 311-325

Pedersen MF, Borum J (1996) Nutrient control of algal growth in estuarine waters. Nutrient limitation and the importance of nitrogen requirements and nitrogen storage among phytoplankton and species of macroalgae. Mar Ecol Prog Ser 142:261-272

Pedersen MF, Borum J (1997) Nutrient control of estuarine macroalgae: growth strategy and the balance between nitrogen requirements and uptake. Mar Ecol Prog Ser 161: 155-163

Pennock JR, Sharp JH, Schroeder WW (1994a) What controls the expression of estuarine eutrophication? Case studies of nutrient enrichment in the Delaware Bay and Mobile Bay Estuaries, USA. In: Dyer KR, Orth RJ (eds) Changes in fluxes in estuaries: implications from science to management. Olsen \& Olsen, Fredensborg, p 139-146 
Pennock JR, Fernandez F, Schroeder WW (1994b) Mobile Bay Data Report: (May 1989 - January 1993). Technical Report 94-001, Marine Environmental Consortium, Dauphin Island Sea Laboratory, Dauphin Island, AL

Pennock JR, Boyer JN, Herrera-Silveira JA, Iverson RI, Whitledge TE, Mortazavi B, Comin FA (1999) Nutrient behavior and phytoplankton production in Gulf of Mexico estuaries. In: Bianchi TS, Pennock JR, Twilley RR (eds) Biogeochemistry of Gulf of Mexico estuaries. John Wiley \& Sons, New York, p 109-162

Pregnall AM, Rudy PP (1985) Contribution of green macroalgal mats (Enteromorpha spp.) to seasonal production in an estuary. Mar Ecol Prog Ser 24:167-176

Rafaelli DG, Raven JA, Poole LJ (1998) Ecological impact of green macroalgal blooms. Oceanogr Mar Biol Annu Rev $36: 97-125$

Raven JA, Taylor R (2003) Macroalgal growth in nutrientenriched estuaries: a biogeochemical and evolutionary perspective. Water Air Soil Pollut Focus 3:7-26

Rosenberg G, Ramus J (1982) Ecological growth strategies in the seaweeds Gracilaria foliifera (Rhodophyceae) and Ulva Sp. (Chlorophyceae): soluble nitrogen and reserve carbohydrates. Mar Biol 66:251-259

Sachs L (1984) Applied statistics: a handbook of techniques, 2nd edn. Springer-Verlag, New York

Selmer JS, Rydberg L (1993) Effects of nutrient discharge by river water and waste water on the nitrogen dynamics in the archipelago of Goteborg, Sweden. Mar Ecol Prog Ser 92:119-133

Sfriso A, Marcomini A, Pavoni B (1987) Relationships between macroalgal biomass and nutrient concentrations in a hypertrophic area of the Venice Lagoon. Mar Environ Res 22:297-312

Sfriso A, Pavoni B, Marcomini A, Orio AA (1992) Macroalgae, nutrient cycles, and pollutants in the Lagoon of Venice. Estuaries 15:517-528

SKALAR (1996) San ${ }^{\text {plus }}$ systems autoanalyzer handbook of operations. SKALAR, Norcross, GA

Smith SV (1981) Marine macrophytes as a global carbon sink. Science 211:838-840

Sokal RR, Rohlf FJ (1995) Biometry. The principles and prac-

Editorial responsibility: Otto Kinne (Editor-in-Chief),

Oldendorf/Luhe, Germany tice of statistics in biological research, 3rd edn. WH Freeman \& Company, New York

Solomonson LP, Barber MJ (1990) Assimilatory nitrate reductase: functional properties and regulation. Annu Rev Plant Physiol Plant Mol Biol 41:225-253

Stumpf RP, Gelfenbaum G, Pennock JR (1993) Wind and tidal forcing of a buoyant plume, Mobile Bay, Alabama. Cont Shelf Res 13:1281-1301

Syrett PJ (1981) Nitrogen metabolism in microalgae. Can Bull Fish Aquat Sci 210:182-210

Thomas TE, Harrison PJ (1985) Effect of nitrogen supply on nitrogen uptake, accumulation, and assimilation in Porphyra perforata (Rhodophyta). Mar Biol 85:269-278

Thybo-Christesen M, Rasmussen MB, Blackburn TH (1993) Nutrient fluxes and growth of Cladophora sericea in a shallow Danish bay. Mar Ecol Prog Ser 100:273-281

Timmermans KR, Stolte W, de Baar HJW (1994) Iron-mediated effects on nitrate reductase in marine phytoplankton. Mar Biol 121:389-396

Tsokos CP (1972) Probability distributions: an introduction to probability theory with applications. Duxberry Press, Belmont, CA

Valiela I, McClelland J, Hauxwell J, Behr PJ, Hersh D, Foreman K (1997) Macroalgal blooms in shallow estuaries: controls and ecophysiological and ecosystem consequences. Limnol Oceanogr 42:1105-1118

Wafar MVM, Corre P le, Birrien JL (1989) Transport or carbon, nitrogen, and phosphorus in a Brittany River, France. Estuar Coast Shelf Sci 29:489-500

Wheeler PA, Björnsäter BR (1992) Seasonal fluctuations in tissue nitrogen, phosphorus, and N:P for five macroalgal species common to the Pacific northwest coast. J Phycol 28:1-6

Wheeler WN, Srivastava LM (1984) Seasonal nitrate physiology of Macrocystis integrifolia Bory. J Exp Mar Biol Ecol 76:35-50

Winer BJ, Brown DR, Michels KM (1991) Statistical principles in experimental design, 3rd edn. McGraw-Hill, Boston, MA

Zar JH (1999) Biostastical analysis, 4th edn. Prentice Hall, Upper Saddle River, NJ

Submitted: March 17, 2004; Accepted: November 25, 2004

Proofs received from author(s): April 19, 2005 